\title{
Geochemical evidence for water column sulfidic holomixia in the sediment of a marine lake
}

IRENA CIGLENEČKI-JUŠIĆ, MILAN ČANKOVIĆ, MARIJA MARGUŠ, SARAH MATEŠA, NIKI SIMONOVIĆ, MATHIEU DUTOUR-SIKIRIĆ AND NEVENKA MIKAC

Ruđer Bošković Institute

Presenting Author: irena@irb.hr

Rogoznica Lake (RL) on the Adriatic coast $\left(43^{\circ} 32^{\prime} \mathrm{N}\right.$, $\left.15^{\circ} 58^{\prime} \mathrm{E}\right)$ is a typical example of the euxinic marine environment that depending on meteorological conditions fluctuates between anoxic holomictic and meromictic conditions. The Lake is strongly stratified during the season into upper oxic and anoxic deeper water layers, with the mixolimnion which varies seasonally (yearly) in depth. At the oxia-anoxia boundary, a pinkish coloured chemocline (up to $50 \mathrm{~cm}$ ) develops seasonally, where anoxygenic phototrophs represented by a dense population of purple sulfur bacteria (PSB), contribute to a relatively high presence of $\mathrm{S}(0)$ in the chemocline and bellow.

Euxinic water layer (mM conc. of $\left.\mathrm{HS}^{-}\right)$and sulfidic sediment are enriched with organic matter (OM) and sulfur. Laminated sediments are highly enriched with Mo $(20-80 \mathrm{mg} / \mathrm{kg})$ along the whole profile with several distinct maxima of $\mathrm{Mo}, \mathrm{Mn}$ and $\mathrm{Fe}$, followed by several other trace elements $(\mathrm{Co}, \mathrm{Ni}, \mathrm{Tl})$ associated with redox cycling of Fe and Mn. Elemental analysis $(\mathrm{C}, \mathrm{S}, \mathrm{N})$ of RL sediment indicates that it is a large sink of $S$, especially $S(0)$ via naturally-occurring sulfurization processes as evident by the high $\mathrm{C} / \mathrm{S}$ ratio $(\sim 9)$. The $\mathrm{C} / \mathrm{N}$ ratio $(\sim 8.6)$ indicates that $\mathrm{OM}$ in $\mathrm{RL}$ sediments is freshly produced and of planktonic origin. Freshly produced $\mathrm{OM}$ is preferable food for sulfate-reducing bacteria as main producers of $\mathrm{HS}^{-}$which accumulates in the euxinic layer on a seasonal and yearly basis. $\mathrm{HS}^{-}$fuels PSB, which depending on ecological conditions shifts to green sulfur bacteria. Bacterially-produced inorganic $\mathrm{S}$ species, like $\mathrm{HS}^{-}, \mathrm{S}_{\mathrm{x}}{ }^{2-}$, or $\mathrm{S}(0)$, are potential agents for the reaction with the OM.

$\mathrm{RL}$ undergoes partial vertical mixing in autumn. Every several years a strong and complete mixing of water column occurs, but quickly restratifies and becomes intensely sulfidic during the succeeding year. Such water column fluctuations greatly influence the lake's geomicrobiology, water column distribution and deposition of Mo visible through records of well-developed maxima in sediment. These maximums can be taken as proxies for lake's holomictic, sulfidic events in the past.

Financial support of MARRES 1717 project is highly acknowledged. 